\title{
Stock Index Performance of SRIKEHATI 2014: Case Study of ISAT and MEDC
}

\section{Fanny Septina}

International Business Management, Universitas Ciputra Surabaya

\begin{abstract}
This study analyzes the returns volatility of ISAT and MEDC in context of green investment. These two stocks are member of SRIKEHATI index. SRIKEHATI is an index containing stocks that concern on environment, social and governance. The period of analysis cover 2009-2014 the focus of the study is on three measures of price earning ratio (PER) and fundamental performance indicator, environment activities disclosure in sustainability report was done. Results show that return volatility of ISAT affects return index of SRIKEHATI significantly, but not for MEDC. ISAT has experienced decreasing profit that continued to a loss, inconsistent reporting environment activities in sustainalibility report. MEDC has experienced decreasing of profit but did not lead into a loss. MEDC is also consistent in reporting environment-related activities through publishing sustainability reports.
\end{abstract}

Corresponding Author:

Fanny Septina

fanny.septina@yahoo.com

Received: 30 December 2019

Accepted: 29 January 2020

Published: 6 February 2020

Publishing services provided by

Knowledge E

(c) Fanny Septina. This article is distributed under the terms of the Creative Commons

Attribution License, which

permits unrestricted use and redistribution provided that the original author and source are credited.

Selection and Peer-review under the responsibility of the 6 th ICOEN 2019 Conference Committee.
G OPEN ACCESS
Keywords: green finance, green investment, SRI-KEHATI index, ISAT, MEDC.

\section{Introduction}

Global warming and climate change have given quite a significant impact on the balance of the economy. A foundation that cares for the environments, Kehati Foundation, liaised with Indonesian Stock Exchange (ISE) launched the SRIKEHATI index that refers on sustainable and responsible investment (SRI) on July 8th, 2009. SRIKEHATI index aims to help investors or the community who wants to invest in stocks that are owned by positive prospects that prioritize mindfulness towards the environment. Selected companies in SRIKEHATI index are considered to have various forms considerations toward the environment, company management, community involvement, human resources, human rights, and ethical business attitudes considerations within the business that are accepted at an international level [15].

Companies that were selected into the SRIKEHATI index have to pass three-stage selection processes. The first stage is the filtering stage for businesses that do not operate in the area of pesticide, nuclear, weapon, tobacco, alcohol, pornography, casino, 
and genetically modified organism (GMO). The second selection stage considers the financial aspects, such as of more than IDR 1 trillion market capitalization value, total asset of more than IDR 1 trillion, free float rate value of more than 10\% (free float is the public owned portion of the share), and positive price earnings ratio (PER) value. The third selection stage considers the fundamentals of the business management, environment, community service, business attitude, human resource and human rights $[15,22]$. The evaluation and the exchange of input and output of SRIKEHATI stocks index are performed every 6 months on May and November [22].

\section{Methods}

This study examines the stock index of SRIKEHATI from 2009 to 2014. The two companies are used as the case study, namely PT. Indosat Tbk and PT. Medco Energi Tbk were declined from SRIKEHATI index 2014. The observation of financial performance of ISAT and MEDC follow the three-stage selection processes SRIKEHATI index. PER (price earnings ratio) shows how many investors wants invest at those profit amount reported, PERs higher ratio is stronger growth prospect [2]. Fundamental performance observed by environtment and social activities disclosure.

The following regression model tests the effect of ISAT and MEDC return stock on the index return of SRIKEHATI:

$$
r_{\text {SRIKEHATI }}=\alpha_{i}+\beta_{a} r_{I S A T}+\beta_{b} r_{M E D C}+\epsilon_{t}
$$

$r_{\text {SRIKEHATI }}$ is the monthly trading-day return of SRI-KEHATI index

$r_{I S A T}$ is the monthly trading-day return of PT Indosat Tbk.

$r_{M E D C}$ is the monthly trading-day return of PT Medco Energi Indonesia Tbk.

$\alpha_{i}$ is the intercept

$\epsilon_{i}$ is the error coefficient

\section{Results}

The result of the F-Test in Table 1 showed that both ISAT stock return and MEDC stock return affects the return index of SRIKEHATI significantly from the period of July 2009 to July 2014. The result of T-test shows independent variabel stock return of ISAT affects stock market return of SRIKEHATI significantly from the period of July 2009 to July 2014. Stock return of MEDC not affects stock market return of SRIKEHATI. The coefficient correlation test showed that the independent variable explained $36.69 \%$ of 
TABLE 1: F-test for Return Portfolio Regression Model.

\begin{tabular}{l|c|c|c|}
\hline Variable & F-test & \multicolumn{2}{|c|}{ T-test } \\
\hline & & Coefficient & p-value \\
\hline Intercept & ${ }^{*} 0,00000174$ & 0,01675125 & 0,002670193 \\
\hline Return ISAT & & 0,335293451 & ${ }^{*} 0,000000847$ \\
\hline Return MEDC & & 0,090464769 & 0,121407773 \\
\hline
\end{tabular}

Notes: *significantly $\alpha=0,05$ or $<0,05$

Source: Yahoo Finance, Bank Indonesia, prepared by author.

the variance on the dependent variables while the rest are explained by extraneous variables of the regression.

TABLE 2: The Result of the Correlation Test for Return Portfolio Regression Model.

\begin{tabular}{lc} 
Correlation & rSRIKEHATI \\
\hline rSRIKEHATI & 1 \\
rISAT & 0,583122798 \\
rMEDC & 0,187367749
\end{tabular}

Source: Yahoo Finance, Bank Indonesia, IDX, prepared by author.

The correlation test in Table 2 indicated a moderately strong correlation between the stock return of ISAT and the dependent variable of SRIKEHATI index, $r=0,58$ whilst, the correlation with independent variable of MEDC stock return is non-significant, $r=0,18$. This result suggests that Indosat stock is the one that significantly impact the event.

\section{Discussion}

\subsection{Financial and fundamental performance of ISAT}

According to the summary of financial performance in Table 3, Indosat had experienced a sharp decrease on its net profit margin, which led to a loss that consequently reduces the PER and earning per share (EPS). Indosat's 2011 annual report stated that a treeplanting program was held to support the government's 1 million tree-planting program and Base Transceiver Station (BTS) that are environmentally friendly. The use of costefficient battery as electric energy supply reserves replaced one of the two diesel power plants in 2011 where batteryis used in 760 locations. Furthermore, to optimize the performance of the battery, Charge Discharger Controller (CDC) switch was implemented. Beyond cost-saving strategy, the purpose of the implementation is to reduce carbon 
waste. The use of fluidic battery is to replace the traditional lead acid battery, where it produces toxic waste that is dangerous if irresponsibly disposed.

In 2012, Indosat built more than 100 solar powered BTS in regions located within 5 hours distance from cities or remote areas to replace the use of diesel power. In 2013 , Indosat report these programs and still reported in the 2014 [11]. One million planting activity reported in 2010-2011 was done [9]. Budget allocation for Indonesia Hijau as shown in Indosat's annual report 2011 [9], takes over 1\% in 2010 and 0\% in 2011. The disclosure of environtment and social activities in sustainability report did not specifically mention the type and the costs spent for these activities.

TABLE 3: Financial Performance of ISAT and MEDC.

\begin{tabular}{|c|c|c|}
\hline Indicators & ISAT & MEDC \\
\hline Market Capitalization & 37.222 .444 .475 .000 & 8.564 .400 .226 .500 \\
\hline Total Assets (billion rupiah) & 53.254 .841 & 33.607 .629 \\
\hline Free Float Rate & $20,71 \%$ & $18,83 \%$ \\
\hline \multicolumn{3}{|l|}{ PER } \\
\hline 2009 & 17,14 & 38,65 \\
\hline 2010 & 40,82 & 11,29 \\
\hline 2011 & 32,91 & 8,45 \\
\hline 2012 & 40,02 & 92,26 \\
\hline 2013 & $-8,11$ & 45,33 \\
\hline 2014 & 12,48 & 82,83 \\
\hline \multicolumn{3}{|l|}{ EPS } \\
\hline 2009 & 276 & 63 \\
\hline 2010 & 132 & 299 \\
\hline 2011 & 172 & 287 \\
\hline 2012 & 89,7 & 36,54 \\
\hline 2013 & $-511,97$ & 46,33 \\
\hline 2014 & $-365,7$ & 37,74 \\
\hline \multicolumn{3}{|l|}{ NPM: } \\
\hline 2009 & 0,08 & 0,03 \\
\hline 2010 & 0,04 & 0,1 \\
\hline 2011 & 0,05 & 0,08 \\
\hline 2012 & 2,17 & 2,01 \\
\hline 2013 & $-11,18$ & 1,8 \\
\hline 2014 & $-7,71$ & 1,83 \\
\hline
\end{tabular}

Source: BEI, prepared by the author 


\subsection{Financial and fundamental performance of MEDC}

According to the summary of financial performance in Table 3, Medco experienced an insignificant increase and decrease of net profit margin, and similarly with PER. However, Medco's EPS value plunged drastically although it did not go to a position of loss. As stated in Medco Energi's 2014 sustainability report, the energy consumption report stated that Medco Energi's energy consumption went down from 8.06-terajoule per barrel oil equivalent (TJ/BOE) in 2010 to $7.62 \mathrm{TJ} / \mathrm{BOE}$ by the end of 2014.

Medco Energi had successfully reduce their conventional fuel oil consumption by using gas fuel and biodiesel, making an effort to using LED lights, solar power, to support their operations. Although there is an increase of energy consumption, the intensity of the energy consumption could be suppressed by $7 \%$ annually. The 2 million rupiah investment on Aset Rimau has channeled 2.235-kiloliter biodiesel for operational vehicles until the end of 2014 . The implementation of energy-efficient program was able to suppress the amount of greenhouse gas emission as high as $29.74 \%$ as compared to conventional operations method.

Medco Energi has built a manufacturing facility of compost through conventional and modern methods using compost tools. Compost is utilized for greening activities. This activity is able to reduce around $7.11 \%$ of the total in organic waste amount that is produced by Aset Rimau. Medco Energi advocates a number of local government supported national projects, such as Mangrove and Proboscis Monkey Conservation Reserves in Tarakan City, rehabilitation of Rambang Dangku Wildlife Reserves with the Conservation Agencies of Natural Resources of South Sumatra.

Medco is committed to reducing carbon dioxide emission from 30 million tons $\mathrm{CO}_{2} \mathrm{e}$ in 2010 into 5 million tons $\mathrm{CO}_{2} \mathrm{e}$ in 2012 [12]. It was decline continously at about 2 million tons $\mathrm{CO}_{2} \mathrm{e}$ in 2013 and 600.000 tons $\mathrm{CO}_{2} \mathrm{e}$ in 2014 [12]. Medco Energi reported environment-related activities and have consistently support greening programs. As a company where their production process is always linked to the availability of natural resources, Medco have performed their responsibility to help guard and preserve the environment as well as providing transparency of such information to the public. Medco awarded PROPER Emas Awards by Indonesian Minister of Environtment for assets Rimau since 2011 to 2014 [12].

A study about sustainability by Eccles, loannou and Serafeim (2016) stated that "highsustainability" companies such Medco Energi is superior than "low-sustainability" both in securities market and accounting measurement, while market does not want that. The research show that "high-sustainability" companies have better performance of B2C 
(business-to-costumer), branding competitiveness, human capital and dependency on natural resources. Zulkafli, Ahmad, and Ermal (2016) state that SRIKEHATI index securities performance has underperform annual mean return, ESG (environtment, social, governance) screening cause additional administration fee. The risk of SRIKEHATI index securities higher than conventional index securities Jakarta Composite Index, filtering process of green investment SRIKEHATI index securities makes higher volatility. Alot of investors attract to invest in green project/assets but it is difficult to find disclosure information about environtment and social activities, those will rise search costs. SRI index is one of performance assesments tools related to environtment. The lack of information and policies makes investors not aware to external risk energy renewal and energy savings [7].

\section{Conclusion}

The volatility of Indosat stock return affects the index return of SRIKEHATI significantly. Indosat experienced a continuous decrease of profit that lead to a loss from year 2009 to 2014. This is related to the PER performance where the value continues to drop to the negatives and the inconsistency of reporting environtment activities. The volatility of Medco stock returns did not affect SRIKEHATI index return significantly. Medco experienced a decrease of profit, however, it did not lead to a loss. PER value experienced a drastic decline. Medco is consistent with its ESG reporting by publishing sustainability reports that encompasses environmentally supportive and preserving programs. Medco compete with other "greened" BEI listed companies whom have good financial performance, to be listed in SRIKEHATI index.

This study show that the volatility of financial performance produced by net profit margin, earnings per share and price earnings ratio, the publication of programs relating to the environment, and volatility of stock return affects whether the company is accepted or declined from SRIKEHATI company index list.

\section{Funding}

This work was supported by Research and Service Community Department of Universitas Ciputra Surabaya under Internal Research Grant in 2018. 


\section{Acknowledgement}

The authors would like to thank their colleague for their contribution and support to the research. They are also thankful to all the reviewers who gave their valuable inputs to the manuscript and helped in completing the paper.

\section{Conflict of Interest}

The authors have no conflict of interest to declare.

\section{References}

[1] Barnea, A., Heinkel, R., \& Kraus, A. (2003). Green Investors And Corporate Investment.

[2] Bodie, Z., Kane, A., \& Marcus, A. J. (2011). Investments and Portfolio Management, Ninth Edition, Singapore: McGraw-Hill Irwin.

[3] Chowdury, T., Datta, R., \& Mohajan, H. (2013). Green Finance Is Essential For Economic Development And Sustainability. International Journal Of Research In Commerce, Economics \& Management, Vol. 3 (2013), No.10 (October).

[4] Eccles, R.G., Ioannou, I., \& Serafeim, G. (2018). The Impact of Corporate Sustainability on Organizational Processes and Performance. Electronic copy available at: http: //ssrn.com/abstract=19640, access on August, 10th,2018.

[5] Eichholtz, P., Kok, N., \& Yonder, E. (2012). Portfolio Greenness And Financial Performance Of REITs. Journal Of International Money And Finance XXX (2012) 1-19.

[6] Ganda, F., Ngwakwe, C.C., \& Ambe, C. (2015). The Role Of Corporate Green Investment Practices On Sustainable Development. Environmental Economics, Vol. 6 , Issue 1.

[7] G20. Green Finance Synthesis Report, 5 September 2016, G20 Green Finance Study Group

[8] Indosat. (2017). https://indosatooredoo.com/en/investor-relation/informasikeuangan/laporan-tahunan. Access on June 2017.

[9] Indosat. (2011). Laporan Tahunan 2011. Access on September 2017: https:// indosatooredoo.com/en/investor-relation/informasi-keuangan/laporan-keuangan.

[10] Indosat. (2012). Laporan Tahunan 2012. Access on September 2017: https:// indosatooredoo.com/en/investor-relation/informasi-keuangan/laporan-keuangan. 
[11] Indosat. (2013). Laporan Tahunan 2013. Access on September 2017: https:// indosatooredoo.com/en/investor-relation/informasi-keuangan/laporan-keuangan.

[12] Indosat. (2014). Laporan Tahunan 2014. Access on September 2017: https:// indosatooredoo.com/en/investor-relation/informasi-keuangan/laporan-keuangan.

[13] Lindenberg, Nannette. (2014). Definition of Green Finance. German Development Institute / Deutsches Institut fur Entwicklungspolitik (DIE).

[14] Medco. (2017). Laporan Keberlanjutan 2014. http://www.medcoenergi.com/id/ subpagelist/view/35. Access on July 2017.

[15] Kehati Foundation. (2017). http://www.kehati.or.id/indeks-sri-kehati/, accesses on 24 Januari 2017-07-10.

[16] Sustainability Report. http://sra.ncsr-id.org/indosat/. Access on July 2017.

[17] The UNEP, AsrlA, International Finance Corporation. (2015). Towards a Sustainable Financial System in Indonesia. UNEP.

[18] Volz, Ulrich. (2016). Fostering Green Finance in Asia. German Development Institute / Deutsches Institut fur Entwicklungspolitik. DIE.

[19] Zulkafli, A.H., Ahmad, Z., \& Ermal, E. The Risk And Return Profiles Of SRI In Indonesia: A Study On Sri Kehati Index. Journal Of Insurance And Financial Management, Vol. 2, Issue 2 (2016) 1-17.

[20] www.bi.go.id

[21] www.financeyahoo.com

[22] www.idx.co.id

[23] www.investing.com 